\title{
Monitoring of Coastline Changes in Gerokgak Sub- District In 1995-2020 Using Grid Method
}

\author{
I Gst Ngr Yoga Jayantara ${ }^{1}$, I Gede Yudi Wisnawa ${ }^{2}$ \\ \{yoga.jayantara@undiksha.ac.id'1,yudi.wisnawa@undiksha.ac.id²\} \\ Universitas Pendidikan Ganesha, Faculty of Law and Social Sciences ${ }^{12}$
}

\begin{abstract}
Coastal areas have conditions that are under a lot of pressure from various phenomena and activities that occur both on land and sea. One of the consequences of the many phenomena that occur in coastal areas is changes in coastlines. Of the several factors that cause coastlines changes, abrasion is one of the most detrimental factors and can be categorized as a disaster because it has destructive characteristic, such as threatening ecosystems or buildings behind the coastlines. This study aimed to monitor changes in coastlines every five years within a period of 25 years as a basis for disaster mitigation analysis. The extraction of the coastlines is carried out by the on-screen digitization method from the image processed using the composite band RGB method to separate land and ocean areas. After the results of the coastlines extraction were monitored, it was then generally concluded the amount of abrasion that occurs at each observation point that was made using the grid method with a distance of $500 \mathrm{~m}$ along the coastlines in Gerokgak Sub-district. Coastline changes that occur at each point of observation are in the form of varying and not linear values, for example abrasion occurs in the first 5 years and it is possible that accretion occurs in the second 5 years. This research produces information about the point with the largest shoreline change in the form of abrasion at observation point 23 with the abrasion as far as $151.98 \mathrm{~m}$ and the point with the change in the shoreline in the form of the largest accretion at the observation point 61 with an accretion as far as $107.07 \mathrm{~m}$.
\end{abstract}

Keywords: Abrasion; Grid Method; Disaster Mitigation; Gerokgak Sub-District.

\section{Introduction}

Gerokgak sub-district is a sub-district located in the western part of the Buleleng Regency area. Gerokgak sub-district consists of 14 villages with 12 villages bordering the sea to the north [1]. Of the total $157.05 \mathrm{~km}$ coastlines length of Buleleng Regency, $48.95 \%$ of the coastlines are in Gerokgak Sub-district thus causing development carried out in Gerokgak Sub-district to focus on coastal areas. This is also influenced by the topography of the Gerokgak sub-district which tends to be hilly in the south so that it tends to be difficult to carry out development in the area [2], [3]. Coastal areas have conditions under a lot of pressure from various phenomena and activities that occur on land or sea since these areas are transitional areas between land and sea [4]. One of the consequences of these phenomena is coastline changes. Coastline change is basically continuous process due to natural activities in the form of abrasion and accretion caused by longshore current and sediment movements, wave activity, and land use [5]. Gerokgak Sub-District has experienced a significant coastline changes in a period of 20 years from 1997 to 2017. The largest change is around 620.6 meters [3]. 
From several factors causing coastline changes, abrasion is one of the most detrimental factors. Coastline changes cause by abrasion can be categorized as a disaster since it is destructive and detrimental, such as threatening ecosystems and buildings behind the coastline area [6]. Referring to the development trend towards the coastal area in Gerokgak Sub-District, abrasion is a disaster that is quite threatening for most of the people living there. Celukan Bawang Steam Power Plant (PLTU), hotels and temples on the beach, fish ponds owned by the government and private communities will certainly be affected [7].

Analysis of coastlines changes would later be generated from coastlines extraction every five years over a period of 25 years. The extraction of the coastlines would be carried out by the on-screen digitization method from the image processed using the composite band RGB method to separate land and sea areas. There would be 6 coastlines resulting from coastlines extraction in $1995,2000,2005,2010,2015$, and 2020. Of the six samples of coastline data produced would be monitored to conclude in general, the amount of abrasion that occurs at each observation point made that was made using a grid with a distance of $500 \mathrm{~m}$ along the coastlines at Gerokgak Sub-istrict. The results of this study are the magnitude of the value of changes in the coastlines, both abrasion and accretion, at each observation point along the coastlines every 5 years in a period of 25 years which aimed to determine the pattern of abrasion and accretion values that occur along the Gerokgak coastal areas so that predictions of coastlines movements could be made - in which it can later be used as a basis for disaster mitigation analysis in Gerokgak Subdistrict.

\section{Methods}

This study utilized Landsat satellite imagery recordings to obtain general overview data on coastline changes. Those recordings were then used as references to get the abrasion value occurred in the coastal area of Gerokgak Sub-District. Stages conducted in this study can be seen in Figure 1.

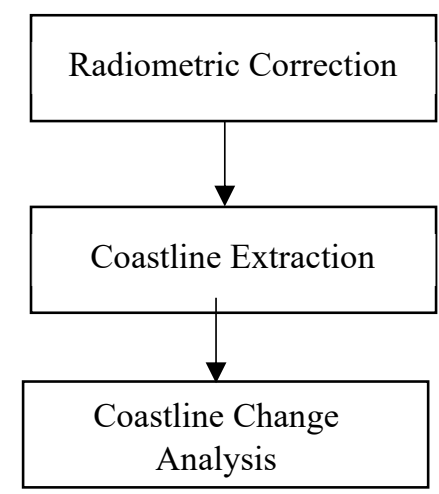

Figure 1. Research Stages

\section{Satellite image correction}

At this stage, the radiometric correction process was carried out using the band composite method. This method is a digital image processing method to get a new image by accentuating certain advantages by combining several bands at one observation time [8]. The band composite method used in this study was band composite RGB method, which combined Red, Green and 
Blue bands in Landsat image to emphasize the difference between land and sea, so that the coastline can be seen more clearly [9]. Landsat 5 and 7 used 457 band combination, while Landsat 8 used 568 band combination [10]. Sample of composite RGB results can be seen in Figure 2 .
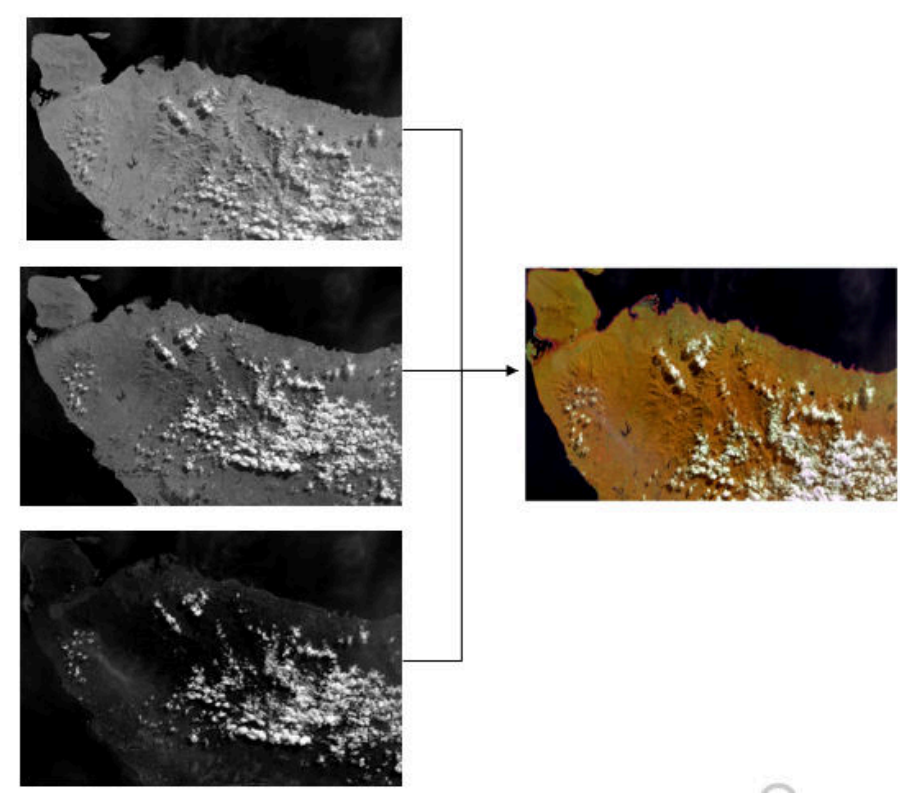

Figure 2. Results of composite RGB on Landsat 8 imagery in 2020

\section{Coastline extraction}

Coastline extraction was performed using a visual interpretation method (digitizing on screen) on the resulting image of band composite RGB in 1995, 2000, 2005, 2010, 2015, and 2020. The digitization results were in the form of 6 coastlines where the changes were observed. Observation points were made every $0.5 \mathrm{~km}$ using the grid method. The abrasion and accretion values from the observations of the six coastlines were analyzed and calculated. The results of coastline extraction can be seen in Figure 3. 


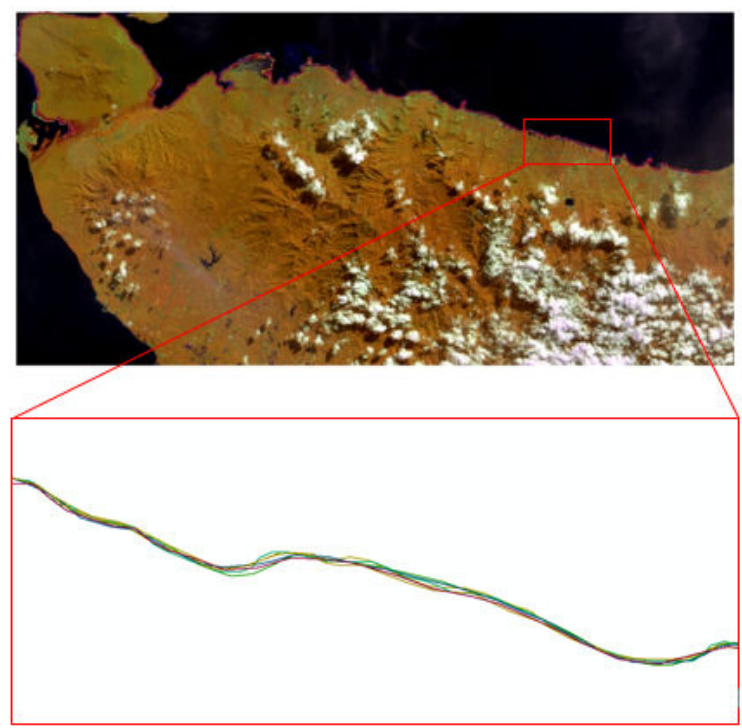

Figure 3. Coastline in 1995-2020

\section{Coastline changes analysis}

The analysis of coastline changes is carried out by calculating the value of changes in the coordinates of the observation points of the six coastlines which have been extracted previously. If the coastline changes protrude toward the sea, it is defined as accretion. On the other hand, if the coastline changes juts inland, it is defined as abrasion. From $\pm 85 \mathrm{~km}$ of coastline along Gerokgak Sub-District, 133 observation points with a distance of $0.5 \mathrm{~km}$ were made using the grid method. The change in the observation point was calculated using the calculation of the distance between 2 coordinate points with the following formula:

$$
D^{2}=(x 2-x 1)+(y 2-y 1)
$$

Based on these calculations, a value will be obtained which will later be defined as the abrasion or accretion value. The following will provide a sample of the observation points that have been carried out.

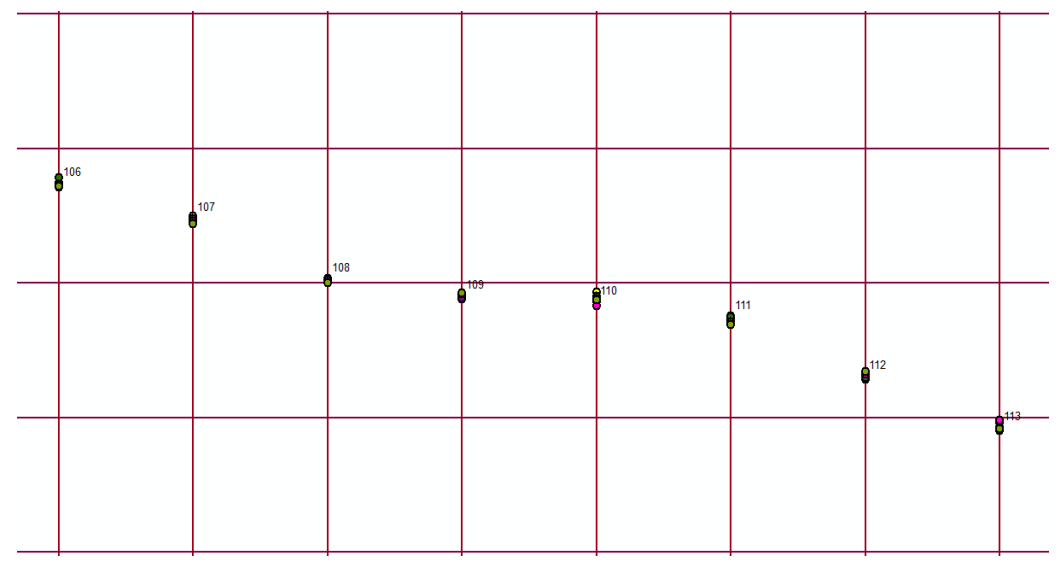

Figure 4. Samples of observation points to obtain abrasion values 


\section{Results and Discussion}

The results of the coastline analysis carried out using the grid method are in the form of abrasion or accretion values observed at 133 observation points. Based on the results of analysis, observation points have changed which vary each year. The distribution of points along the coastline to be monitored for changes can be seen in Figure 5.

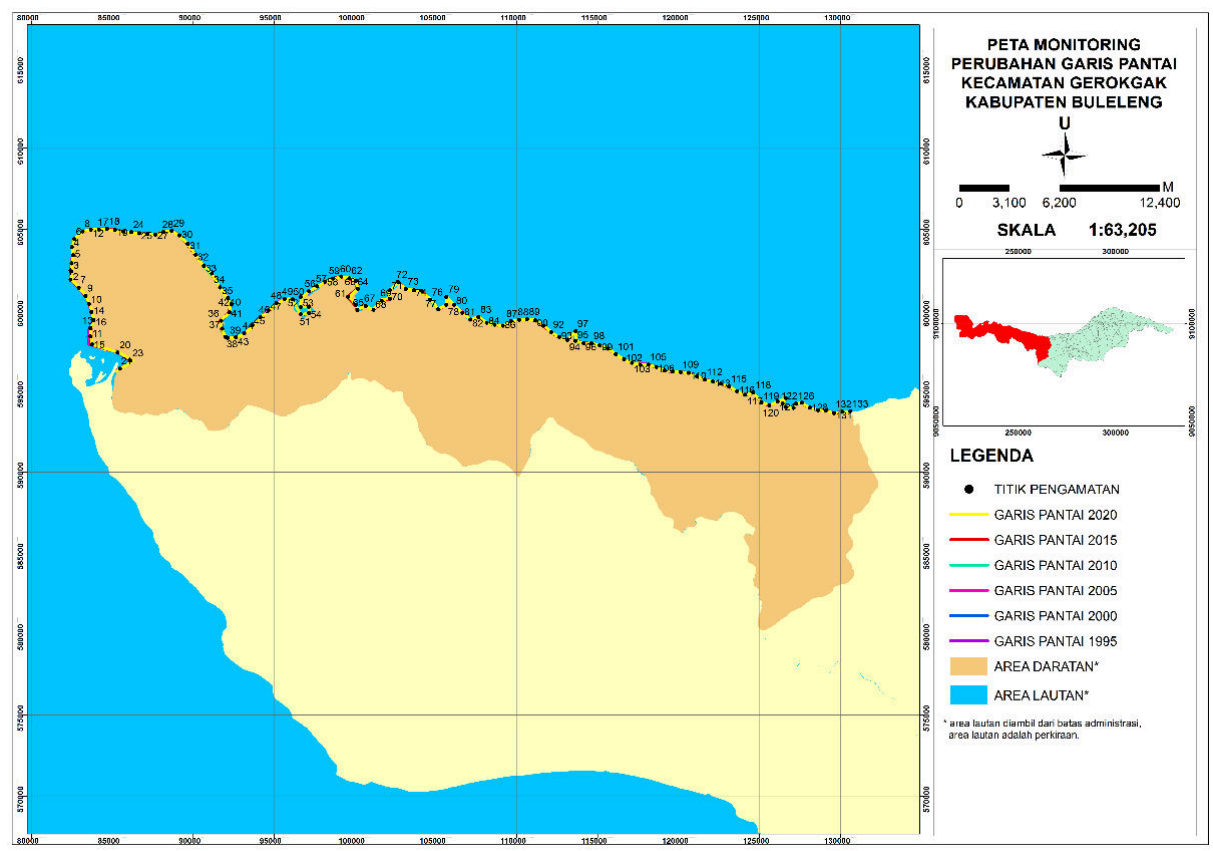

Figure 5. Distribution of points to be monitored

The changes in the observation point that juts out towards the land describe abrasion, while the changes in the observation point that juts out towards the ocean describe accretion. For example, at the 11th observation point, it can be seen that there was accretion in the first five years, while that point experienced abrasion in the observation span of the second five years. Thus, the changes in the coastline were not linear. The results of monitoring of coastline changes are presented in

Based on the results of observations using the grid method, 133 abrasion and accretion values were obtained which were then added linearly. It then obtained the final value; if the accretion is more dominant, the point of observation in general experiences a change in the form of accretion and if the abrasion is more dominant, the point of observation in general experiences changes in the form of abrasion.

Some points that experienced changes in the form of quite extreme abrasion were point 20 with an abrasion of $108.38 \mathrm{~m}$, point 23 with an abrasion of $151.98 \mathrm{~m}$, and point 34 with an abrasion of $102.66 \mathrm{~m}$. Furthermore, points that experienced changes in the form of quite extreme accretion were point 61 with accretion of $107.07 \mathrm{~m}$, point 65 with accretion of $66.97 \mathrm{~m}$, and point 69 with accretion of $76.57 \mathrm{~m}$. Based on these values, some spots that have been damaged due to abrasion can be identified. Therefore, the competent authority can make decisions about what mitigation steps can be taken as an attempt to minimize the damage that occurs in the future. 


\section{Conclusion and Suggestion}

Based on the results, this study concludes that: 1) Coastline changes that occur at each point of observation are in the form of varying and not linear values, for example abrasion occurs in the first 5 years and it is possible that accretion occurs in the second 5 years. 2) The point with the coastline changes in the form of the largest abrasion can be found at observation point 23 with the abrasion of $151.98 \mathrm{~m}$ and the point with the coastline changes in the form of the largest accretion can be found at the observation point 61 with an accretion of $107.07 \mathrm{~m}$. This research is considered to have shortcomings. Thus, further research is expected to make development and improvement such as using tide data in determining abrasion and accretion so that the results can be more accurate.

\section{References}

[1] BPS, Kecamatan Gerokgak Dalam Angka, no. ISSN: 2502-0471. Singaraja: BPS Kabupaten Buleleng, 2018.

[2] BPS, Kabupaten Buleleng Dalam Angka, no. ISSN: 0215-5389. Singaraja: BPS Kabupaten Buleleng, 2018.

[3] I. N. P. Indrawan, A. Damayanti, and A. Rustanto, "Penggunaan Citra Landsat Untuk Analisis Perubahan Garis Pantai Akibat Perubahan Penggunaan Tanah," in Seminar Nasional Geomatika, 2017, vol. 2, pp. 437-443.

[4] K. Damaywanti, "Dampak Abrasi Pantai terhadap Lingkungan Sosial (Studi Kasus di Desa Bedono , Sayung Demak)," in Seminar Nasional Pengelolaan Sumberdaya Alam dan Lingkungan, 2013, pp. 363-367.

[5] T. Hariyanto, M. K. Mukhtar, and C. B. Pribadi, "Evaluasi Perubahan Garis Pantai Akibat Abrasi Dengan Citra Satelit Multitemporal (Studi Kasus: Pesisir Kabupaten Gianyar, Bali)," Geoid, vol. 14, no. 1, pp. 66-74, 2018.

[6] M. K. Abda, "Mitigasi Bencana Terhadap Abrasi Pantai Di Kuala Leuge Kecamatan Aceh Timur," J. Samudra Geogr., vol. 02, no. 01, pp. 1-4, 2019.

[7] Nusa Bali, "Hampir Sepertiga Pantai Buleleng Tergerus Abrasi," Nusa Bali, p. 1, 2016.

[8] I. M. A. W. Putra, A. Susanto, and I. Soesanti, "Ekstraksi Garis Pantai Pada Citra Satelit Landsat dengan Metode Segmentasi dan Deteksi Tepi I," J. Nas. Pendidik. Tek. Inform., vol. 4, no. 3, p. 115, 2015.

[9] T. I. Maryanto, W. Windupranata, and S. Bachri, "Studi Perubahan Garis Pantai Berdasarkan Interpretasi Citra Satelit Landsat dan Perhitungan Rasio Lahan di Wilayah Pesisir Indramayu Jawa Barat,” J. Rekayasa Hijau, vol. 1, no. 1, 2017.

[10] K. T. Setiawan, Y. Marini, S. Pusat, and P. Penginderaan, "Bedah Tuntas Data Citra Landsat 8 untuk Wilayah Pesisir dan Laut,”vol. 10, no. 2, pp. 28-34, 2015. 